\title{
The Preacher and the Actor: Bach, Handel and the "Passionate" Listener
}

\author{
By Gerald Neufeld
}

\begin{abstract}
Although treatises on singing from the $17^{\text {th }}$ to the $19^{\text {th }}$ centuries focused singing instructions on solo performance, the principles contained in them were intended to be applied to choral performance as well. Domenico Corri specifies that his treatise The Singers Preceptor or Corri's Treatise on Vocale Music (1810) '...is expressly calculated to teach the Art of Singing ... accommodated to the capacity of every student whether amateur or professional, theatrical, or choral.' This paper explores contrasting rhetorical means employed by Bach in his motet Jesu meine Freude and by Handel in Messiah with implications for choral performance practice. Bach's motet Jesu meine Freude shows a clear relationship between structure and hermeneutics. Employing a familiar rhetorical structure, he states an argument (inventio), gives it clarity through form (dispositio), and presents it using compositional devices consistent with Figurenlehre (decoratio). The listener's passions are moved through Affektenlehre (pronunciatio), thereby eliciting a response to a theological argument. In contrast, Handel reveals the skill of an orator in Messiah where embellishing the text (decoratio or elocutio) forms the basis for an expressive performance (pronunciatio) in the arias and choruses. Bach employs a dialectical approach to elicit a passionate response from his listeners, as would a preacher. Handel moves the passions of his listeners with the oratorical skills of an actor. Understanding these contrasts encourages a more affective performance of the text, thereby achieving Michael Praetorius's admonition to '...sing with art and grace so that the heart of the listener is stirred and the affections are moved.' (Syntagma musicum, tomus tertius, 1619)
\end{abstract}

The relatively recent recognition of the important role played by text declamation in the interpretation of choral music has resulted in a revitalized approach to the performance of familiar works by Bach and Handel. A more complete understanding of the assumptions under which composers labored can inform the way conductors and singers prepare and perform familiar choral works of the Baroque era. In probing those assumptions, one must necessarily explore the role of rhetorical principles and musical-rhetorical figures.

*Associate Professor, Western University, Canada. 
The music of both Bach and Handel was influenced by an understanding of rhetoric. Seventeenth- and eighteenth-century German music wed the discipline of music to rhetoric. The resulting musical-rhetorical approach to composition, referred to as musica poetica by Joachim Burmeister, ${ }^{1}$ required composers to analyze a text from a rhetorical perspective before creating a parallel musical structure that enhanced the affections expressed in the text.

In Bach's Dialogue with Modernity John Butt makes a persuasive argument for Bach's employment of a dialectical approach to a text, much as a preacher of his day would have done. In describing the contrast between rhetoric and dialectic, he begins by describing rhetoric as '...the art which embellishes and amplifies the opinions and outlooks an audience already holds, while dialectical presentation is much more disturbing, designed to bring about a change in the listener.'2

Bach's funeral motets are essentially didactic, using the occasion of the death of an eminent figure in the Leipzig community to preach a sermon to the mourners. The implementation of a dialectical model is entirely in keeping with his role as a church musician. In contrast, Handel's music was more apt to be influenced by the theatre in which, to paraphrase Socrates, rhetoric was used to move the passions of the listener, thus exciting an emotional response to believe rather than making a cogent and convincing argument for belief through dialectic. ${ }^{3}$

Bach's motet Jesu meine Freude, which shows the influence of Lutheran theology and rhetorical practices, illustrates the role of rhetorical structures in his motets. Its primary purpose is didactic employing a text with a dialectical argument. ${ }^{4}$ In contrast, a sampling of Handel's use of musical-rhetorical devices in Messiah shows the influence of a more Italianate approach to the principles of musical rhetoric in his choral compositions.

\section{Bach: Theological and Musical Foundations}

Bach's tenure at the Thomaskirche in Leipzig coincided with the end of a long period of productivity in the Lutheran sphere of church music. Martin Luther viewed musical composition as a divine gift and believed that 'next to the Word of God, the noble art of music is the greatest treasure in this world. ${ }^{, 5}$ Integral to the Lutheran Lateinschule curriculum, music was seen as a necessity for teachers and preachers. In a letter to the composer Ludwig Senfl, Luther insisted that 'we should not ordain young men into the ministry unless they

\footnotetext{
${ }^{1}$ Joachim Burmeister (1606). Musica Poetica, Rostok. Musical Poetics, trans. Benito V. Rivera. New Haven: Yale University, 1993.

${ }^{2}$ John Butt (2012). Bach's Dialogue with Modernity. Cambridge: Cambridge University Press. 248.

${ }^{3}$ Ibid. 248 .

${ }^{4}$ Jesu meine Freude is thought to have been composed for a memorial service for Johanna Maria Kees, the wife of the postmaster in Leipzig, on July 18, 1723. Klaus Hofmann, Preface to J. S. Bach: Motteten, BWV 225 - 230. Kassel: Bärenreiter, 7.

${ }^{5}$ Walter E. Buszin (1946). 'Luther on Music.' Musical Quarterly 32:81
} 
have become well acquainted with music in the schools." ${ }^{1}$ The Reformation's newfound mission to preach the word in the vernacular encouraged the rediscovery of the discipline of rhetoric which, when combined with Luther's views on the centrality of music in worship, was found to be applicable to musical composition. Although a preacher could express a text intellectually, the text and its affection could be communicated more emphatically through a musical setting. Music was considered a heightened form of speech, a rhetorical sermon in sound. It was, therefore, natural for seventeenth-century composers, schooled in the art of rhetoric, to apply the rigors of rhetoric to the art of composition, thereby making them preachers through their music. A funeral motet was considered an appropriate vehicle for preaching as well as for consolation.

\section{Musical-rhetorical Structure: Musica Poetica}

Rhetorical structure, as elucidated by ancient Greek orators such as Aristotle and Cicero and by Quintilian, a first-century Roman rhetorician, consisted of five main steps: inventio, dispositio, elocutio, memoria, and pronunciatio. Of these, inventio, dispositio, and elocutio provided a structural framework for musical composition while pronunciatio found its parallel in performance practice. Inventio concerned itself with the choosing of a subject and dispositio focused on the arrangement and development of material to elucidate the subject. Elocutio, also known as decoratio, set out four 'virtues' or stylistic expectations of which ornatus, the embellishment of a text with figures and tropes (metaphoric expressions), was most relevant to musical composition. Concepts and structures of musica poetica were determined by inventio, dispositio, and elocutio. Pronunciatio concerned itself with a polished delivery, proper vocal inflection, and the addition of gestures to a musical performance.

Johann Mattheson believed that a musical composition should develop in the manner of an oratorical dispositio. ${ }^{2}$ However, it was the composer's skill with elocutio that gave rise to a musical-rhetorical Figurenlehre, so named by twentieth-century musicologists to describe musical figures analogous to figures of speech. Based on text expression, musical figures were the primary means of arousing the affections in the listener. This was accomplished through the application of artful and expressive digressions to simple, unadorned musical idioms and conventional counterpoint. ${ }^{3}$ Employment of these figures,

\footnotetext{
${ }^{1}$ Ibid., 32:85

${ }^{2}$ 'Our musical disposition is different from the rhetorical arrangement of a mere speech only in theme, subject or object: hence it observes those six parts which are prescribed to an orator, namely the introduction, report, discourse, corroboration, confutation, and conclusion. Exordium, Narratio, Propositio, Confirmatio, Confutatio, \& Peraratio.' In the following pages, Mattheson describes how each part is developed. Johann Mattheson (1739). Der vollkommene Capellmeister. Hamburg: Christian Herold. Part II, Chapter 14, § 4, $235 \mathrm{ff}$.

${ }^{3}$ Dietrich Bartel (1997). Musica Poetica: Musical-Rhetorical Figures in German Baroque music. Lincoln: University of Nebraska Press. 84.
} 
whose development can already be seen in the word painting of Renaissance madrigals, was an essential skill for a composer in the seventeenth and early eighteenth centuriesMattheson holds musical figures in high regard, describing them as 'having such a natural position in the melody that it seems as though the Greek orators derived their figures from the musical discipline. ${ }^{1}$

\section{Jesu Meine Freude: Rhetorical Structure}

An overview of the eleven movements of Jesu meine Freude ${ }^{2}$ illustrates a complex rhetorical structure that brings to light the hermeneutical intent of Bach's choice of text for this motet. In it he uses five verses from Paul's epistle to the Romans to frame a theological argument that he embeds between six verses of Johann Crüger's chorale Jesu meine Freude. ${ }^{3}$ A poetic verse from the chorale precedes each section of prose from the book of Romans with the sixth chorale verse ending the motet.

Bach structures his motet like a careful dialectical dispositio in which he argues for a life of the spirit rather than of the flesh. Movement two points out that there is no condemnation in aspiring to a Christian life of the spirit, and movement four insists that the law of the spirit makes us free from the law of sin and death. Movement six contains the pivotal argument that occurs precisely at the midpoint of this eleven-movement palindrome. It points to an unambiguous turning from a fleshly existence to a spiritual life. Movements eight and ten seek to convince us of the proposition that the spirit 'of him who raised Jesus from the dead ... shall live in you.'

From a rhetorical point of view, it would appear that the chorale verses are an affective response to Paul's didactic message. Perhaps surprisingly, it is primarily Paul's theological prose on which Bach lavishes his skills in ornatus. The exception is the chorale text in the fifth movement, for which he employs a spectacular array of musical-rhetorical figures to contrast its text with that which follows in the sixth movement. In the sixth movement Bach articulates the central argument of his dispositio, which is Paul's statement 'for you are not of the flesh, but of the spirit, so differently does God dwell in you' from Romans 8, verse 9. As the central movement of an eleven-movement palindrome, Bach sets these words to a fugue, a form much preferred for expressing ideas of gravity and significance.

It is interesting to note that Bach chooses not to employ the chorale melody in the chorale verse that precedes the pivotal theological argument in movement six. Instead, he throws all his compositional might into musicalrhetorical figures that encourage his listeners to defy the powers of evil and trust in God's protection while standing and singing in secure peace. It is here that Bach makes his argument more persuasive through elaborate use of

\footnotetext{
${ }^{1}$ Mattheson, Ibid., 243, §46.

${ }^{2}$ Johann Sebastian Bach., ed. Konrad Ameln (1965). Neue Ausgabe sämtliche Werke: Motten. Kassel: Bärenreiter. $77-104$.

${ }^{3}$ Chorale melody, 1653, text by Johann Franck, 1650.
} 
musical figures, the equivalent of ornatus in rhetoric, to convince his congregation of the central argument that follows in movement six.

Using examples of the musical-rhetorical figures in movement five, we see how their prominence in conveying affective elements inherent in the text determines the text declamation and, thus, its performance practice, the equivalent of pronunciatio in rhetoric.

\section{Bach's use of Affective Musical-Rhetorical Figures}

The chorale text in movement five begins with the word trotz, which can be interpreted as 'defy' or 'despite' in English. ${ }^{1}$ Bach uses both nuances of this word, first to express defiance of the dragon and his raging, and second to express a sense of doubt with the words trotz der Furcht darzu, despite the fear of it. (See Figure 1a.) The first iteration of trotz is followed by two quarter rests giving it the character of the figure exclamatio defined by Mattheson as 'a true scream which often originates from extreme consternation, astonishment, or from frightful, horrible events, which often ascend to the heights of desperation.' ${ }^{2}$ The repetition of the word trotz is an example of the figure epizeuxis described by Mattheson as one of the most common figures used to express greater vehemence. ${ }^{3}$ It is followed by the figure paronomasia, which occurs 'when an already expressed sentence, word, or saying is repeated with a new, singular, and emphatic addition. ${ }^{4}$ The text trotz dem alten Drachen (defy the old dragon) in measures 147 - 149 is repeated emphatically in unison in measures 150 and 151. In measures 151:2 - 157:1 the music intensifies the text trotz des Todes Rachen (defy Death's revenge) by using the same figures as in the preceding measures.

Measures 157:2 to 160:1 begin with the figure ellipsis that Johann Forkel, Bach's biographer, describes as 'a notable form of expressing a sentiment ... when its expression is suddenly suspended and broken off after a gradual and successively intensifying growth. ${ }^{5}$ Doubt is then sown throughout this passage as the meaning of the word trotz shifts to 'despite' - despite fear of the jaws of death referred to in the preceding phrases. To express this doubt Bach employs a complex form of the familiar figure dubitatio, which Scheibe describes as an affect of uncertainty. He explains that 'the dubitatio must not confuse the composer's own arrangement or the proper coherence of his music... rather he must only meaningfully lead the listeners astray so that, becoming uncertain regarding the order of the music or the notes, they cannot easily guess his

\footnotetext{
${ }^{1}$ Trotz dem alten Drachen, Trotz des Todes Rachen, Trotz der Furcht darzu! Tobe, Welt, und springe, Ich steh hier und singe in gar sichrer Ruh. Gottes Macht hält mich in acht; Erd und Abgrund muss verstummen, Ob sie noch so brummen. Defy the old dragon, Defy the jaws of death, Despite the fear of it! Rage, world, with leaping: I stand here and sing in secure peace. God's might holds me in awe; earth and abyss must fall silent, however much they rumble on.

${ }^{2}$ Mattheson, Der Vollkommene Capellmeister. Part II, Ch. 9, § 67, 194.

${ }^{3}$ Mattheson, Der Vollkommene Capellmeister. Part II, Ch. 14, §45, 243.

${ }^{4}$ Johann Scheibe (1740). Critischer Musicus. Hamburg. 691.

${ }^{5}$ Johann Forkel (1788). Geschichte der Musik. Leipzig. 56.
} 
intent." Overarching these figures is a sense of catabasis or descensus, a descending figure described by Kircher as expressing 'servitude and humility, as well as lowly and base affections ${ }^{2}$ - affections that accompany the fear of the devil that Bach is describing in this complex passage.

It is not surprising that Bach dramatizes the word tobe, to actively rage and rampage, with two simultaneous figures; epizeuxis, the repetition of a word in the upper voices, and hypotyposis, the rising figure in the bass voice. Hypotyposis is a rhetorical figure that Gottsched describes in his Redekunst as a 'detailed description of something, seemingly painting it before the eyes of the listener. ${ }^{3}$ With its musical counterpart in word painting, this figure can also be seen on the verb springe, to leap, which follows in measure 167 with a unison octave leap encompassing the greatest possible harmonic distance. (See Figure 1.)

The unexpected rest in measure 167 in the phrase ich steh hier und singe makes emphatic Bach's declaration 'I stand here and sing' through the use of the figure aposiopesis. It is described in Walther's Musikalisches Lexicon as 'when a silence occurs in the middle of a composition through a whole-, half-, or quarter-beat rest without a preceding ending or cadence. ${ }^{4}$ The text, in which this unusual figure is found, is given more convincing expression through the figure, anabasis, an ascending harmonic figure followed by a rising unison phrase in measures 169 to 171. Kircher describes anabasis as 'a musical passage through which we express exalted, rising, or elevated and eminent thoughts. ${ }^{5}$ Bach employs the same figure later on the words, Erd und Abgrund, (earth and the abyss) in measures $190-193$. (see Figure 1, b.) It is followed by a descending catabasis figure on 'muss verstummen' (must grow silent). The repetition of the word verstummen (to silence) in measures 195 and 196 is an example of paronomasia. This time with the second word, normally the emphatic word, is expressed in a softer tone.

The above sampling of figures illustrates Bach's consummate skill and artistry in applying the principles of decoratio to music, thereby enhancing the message that he seeks to convey to his listeners. It is clear that this tour de force of musical-rhetorical figures is placed before the pivotal sixth movement in order to amplify the central theological argument that 'you are not in the flesh, but in the Spirit.' This movement consists of the figure fuga which, by Bach's time, had developed from an imitative contrapuntal figure into an independent form. Bach's biographer Johann Forkel describes it in superlatives as 'the most splendid, most perfect, and greatest musical genre, the unanimous expression of a people. ${ }^{6}$ In the main thematic material in this fugue, it is interesting to note that Bach employs the figure cirulatio to express the word

\footnotetext{
${ }^{1}$ Scheibe. Critischer Musicus. 686.

${ }^{2}$ Athenasius Kircher (1650) Musurgia Universalis sive ars magna consoni et dissoni. Rome. Bk. 8, 145.

${ }^{3}$ Johann Christoph Gottsched (1736). Ausführliche Redekunst nach Anleitung der Greichen and Römer wie auch der neuern Ausländer. Leipzig: Breitkopf. 283.

${ }^{4}$ Johann Gottfried Walther (1732). Musikalisches Lexicon. Leipzig: Wolfgang Deer. 41.

${ }^{5}$ Kircher, Musurgia. Bk. 8, 145.

${ }^{6}$ Forkel, Allgemeine Geschichte. 48
} 
geistlich (spiritual) with sixteenth-note passage consisting of four beats in a sine wave motion indicating a circle and, by analogy, Godly perfection (measures 211 and 212). It is completed in measure 212, beats three and four, by two beats of gradatio, a rising figure building in intensity. (See Figure 1. c.)

Figure 1. Bach, Jesu Meine Freude - Excerpt from Movement 5
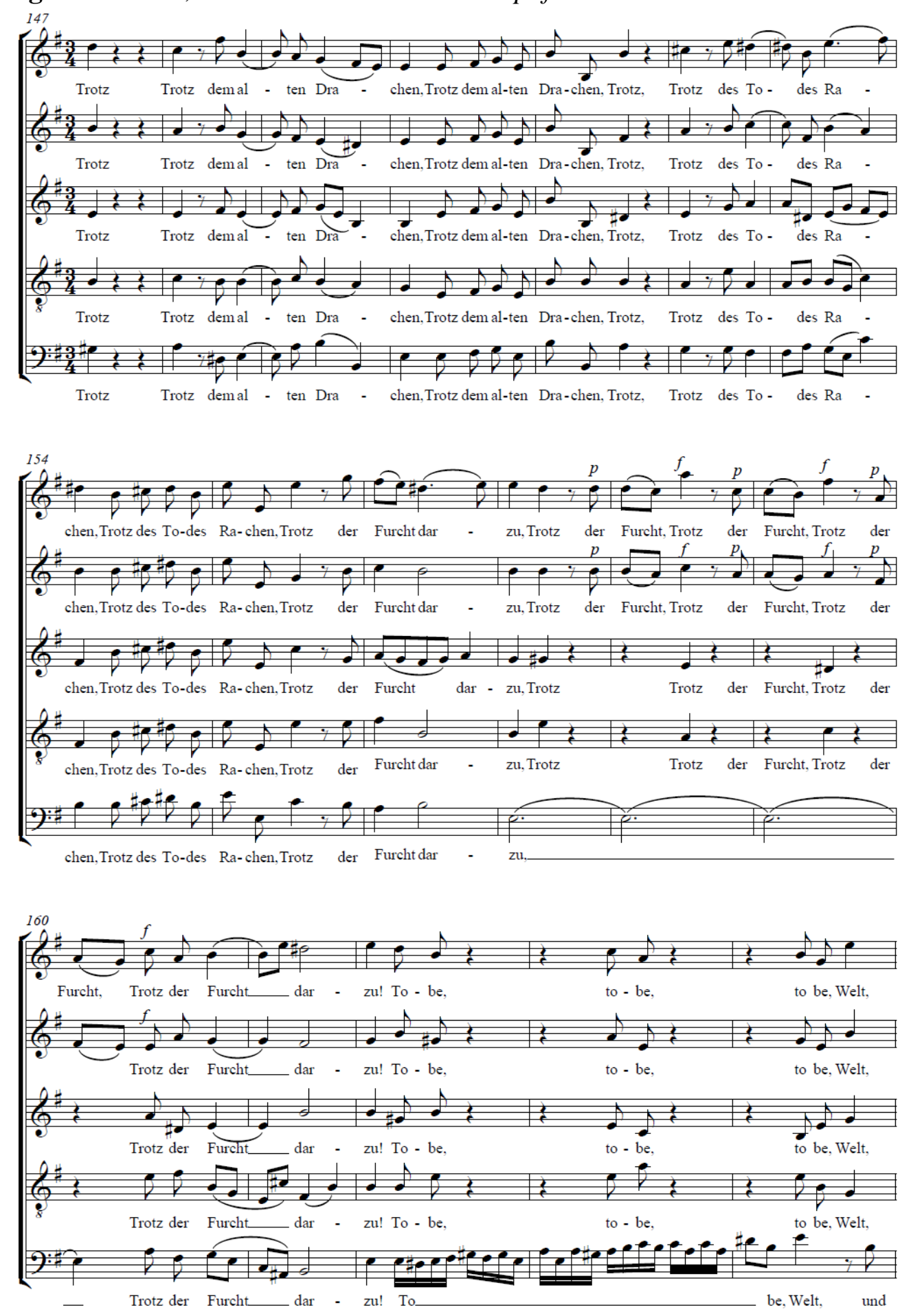


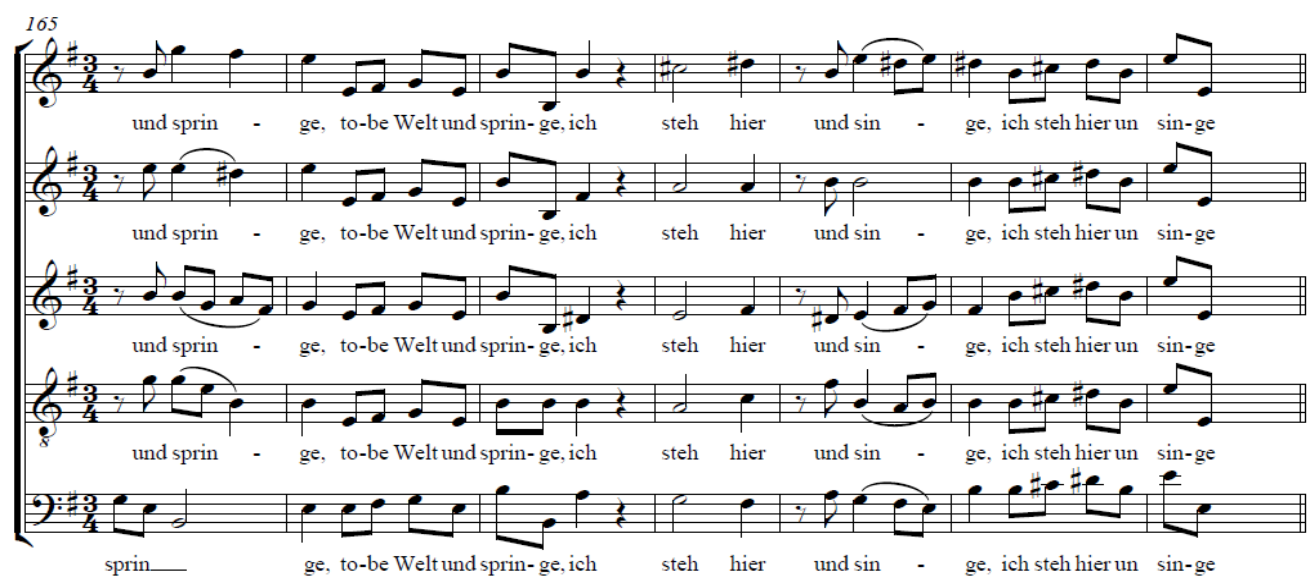

Figure 1a

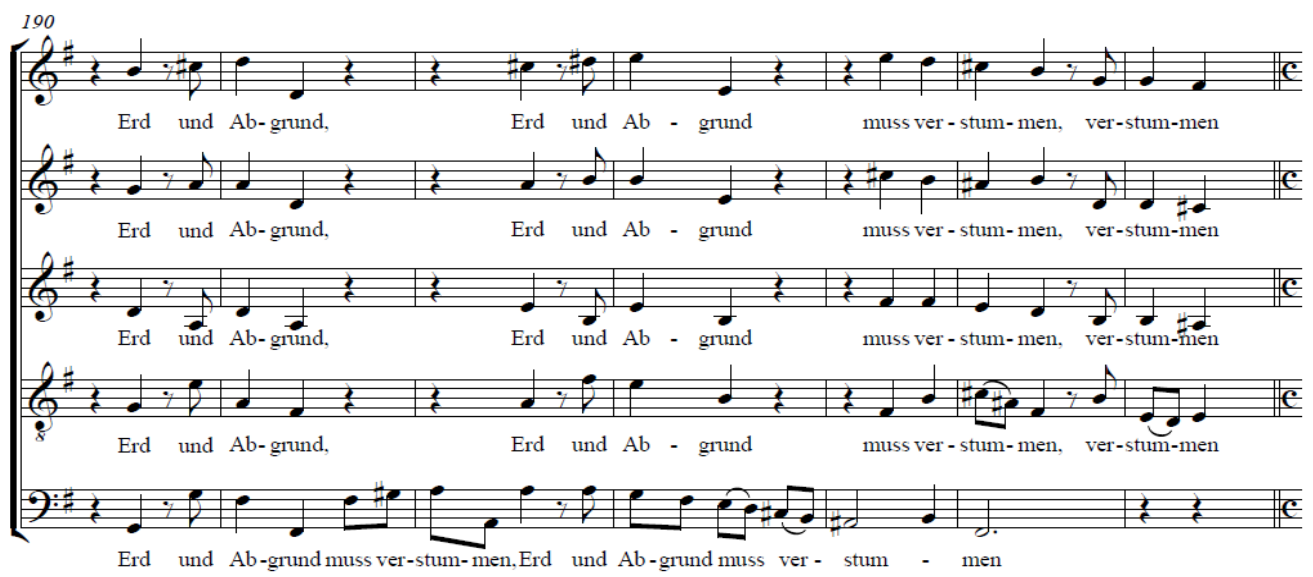

Figure 1b

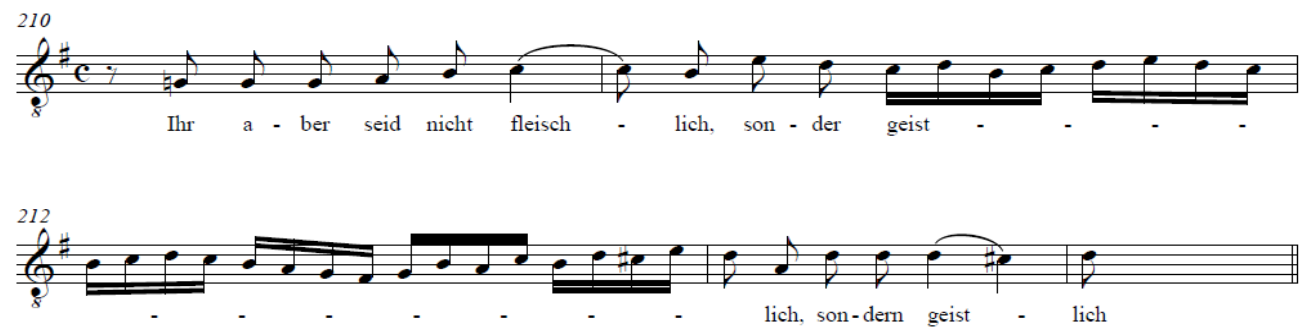

\section{Handel's Use of Affective Musical-Rhetorical Figures}

A brief look at Handel's Messiah illustrates how the use of musicalrhetorical figures can be seen against the backdrop of his experience as a dramatist composing Italian opera for over thirty years. For the dramatist, effectively expressing an affection was more important than presenting a theological argument or viewpoint. Dietrich Bartel points out that the 
prominence given by Italian composers to pronunciatio, the affective aspect of rhetoric, 'was modeled after the art of oratory rather than the discipline of rhetoric. Its goal was to imitate the actor rather than the playwright, the orator rather than the rhetorician. [I]ts direct affective and aesthetic effect led to a form of musical expression which focused on a modern aesthetic principle of expressing and stirring the affections rather than explaining the text. ${ }^{1}$ Thus, the musical-rhetorical figures employed by Handel serve primarily to enhance the drama of Messiah rather than advance a theological argument. ${ }^{2}$

A few examples will suffice to illustrate Handel's approach to rhetorical figures. In the chorus And the Glory of the Lord, four distinct thematic motives employing three figures form the building blocks of this movement as illustrated in Figure 2. Followed by a noëma described by Burmeister as 'a harmonic affection or period that consists of voices combined in equal note values,' this figure occurs in contrast to the surrounding contrapuntal texture, thus conferring greater significance on the words through harmonic emphasis. ${ }^{3}$ (See Figure 3.)

Figure 2. Musical-rhetorical Figures in 'And the Glory of the Lord' from Handel's Messiah

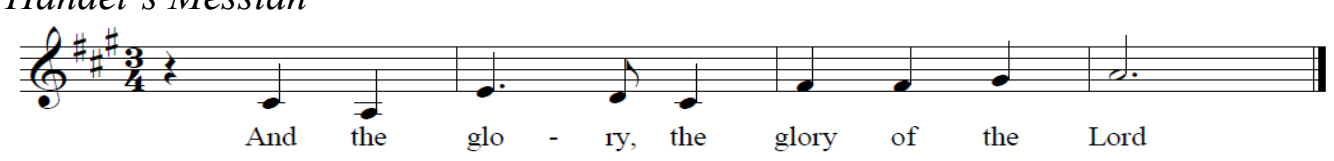

Anadiplosis. '...by which the last word of the first clause is the beginning of the second.'

Henry Peacham the Elder (1593). The Garden of Eloquence. 46.

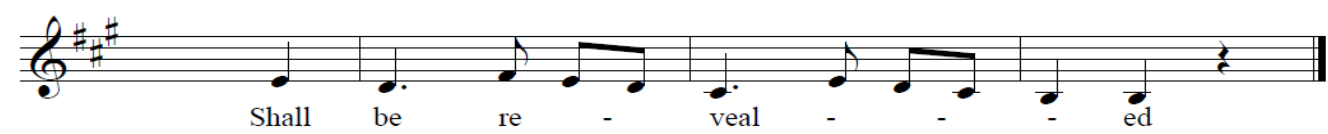

Dimimutio. '...a dissolving or breaking up of a longer note into numerous faster and smaller notes ...in successive stepwise fashion...' Michael Praetorius. Also, hypotyposis, a vivid musical representation of images found in the accompanying text.' (In this case, the word 'revealed.') Bartel (1997). Musica Poetica. 445.

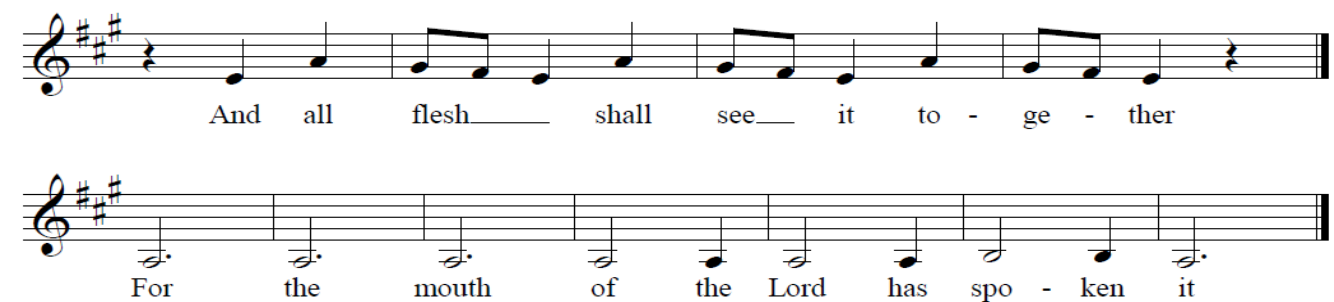

Epizeuxis. 'an immediate and emphatic repetition of a word, note, motive or phrase.' Bartel (1997). Musica Poetica. 444

\footnotetext{
${ }^{1}$ Bartel, Musica Poetica. 59.

${ }^{2}$ It could be argued, however, that the entire oratorio, Messiah, is constructed as a rhetorical argument for the fulfillment of prophetic writings in the advent and life of Jesus, the Messiah. ${ }^{3}$ Burmeister (1606). Musica Poetica. 165.
} 
Figure 3. Noëma. 'And the Glory of the Lord' from Handel's Messiah. '...harmonic affection or period that consists of voices combined in equal note values.' Burmeister, Musica Poetica

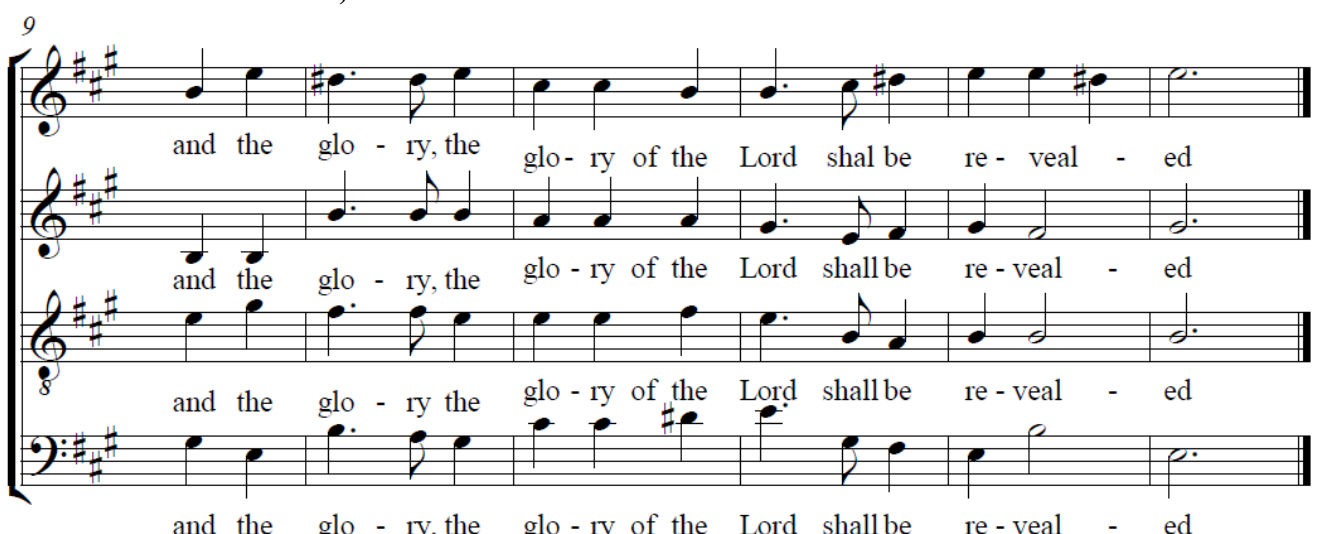

Handel seems to favor the use of anadiplosis described by Henry Peacham the Elder as constructed ' $[\mathrm{b}] \mathrm{y}$ which the last word of the first clause is the beginning of the second.' ${ }^{1}$ Examples of this figure can be seen in the following texts from Messiah: 'Thus saith the Lord, the Lord of hosts,' 'He was despised, despised and rejected,' and 'the Lord hath laid on him, hath laid on him the iniquity of us all.' Epizeuxis, the repetition of a word or phrase at the beginning of a sentence, appears repeatedly throughout Messiah: 'Comfort ye, comfort ye my people,' 'Glory to God, glory to God in the highest,' 'Rejoice, rejoice, rejoice greatly, rejoice, O daughter of Zion,' 'Surely, surely he hath borne our griefs. ${ }^{2}$ Circulatio is found in the chorus Their Sound is Gone Out as a rising and falling eighth-note figure encompassing an octave on the text 'and their words unto the ends of the world.' Hypotyposis can easily be seen in the opening measures of the chorus Behold the Lamb of God as an upward pointing gesture and, in the chorus For unto us a child is born, the designations 'Wonderful, Councilor, the mighty God, the everlasting Father, Prince of Peace' form a striking example of congeries. Peacham describes congeries as 'a multiplication or heaping together of manye wordes, signifying dyvers things of like nature. ${ }^{3}$

\section{Applications to Historically Informed Performance Practice}

How does an understanding of rhetoric and its analogous musical figures aid us with a historically informed performance practice? Being cognizant of the central argument in Jesu meine Freude prompts the singers to give greater

\footnotetext{
${ }^{1}$ Henry Peacham the Elder (1593). The Garden of Eloquence. London. 46.

${ }^{2}$ 'Epizeuxis is a figure whereby a word is repeated, for the greater vehemencie, and nothing put between: and it is used commonly with a swift pronunciation.' Henry Peacham the Elder. Ibid. 47.

${ }^{3}$ Henry Peacham the Elder (1577). The Garden of Eloquence. Qii. Menston: The Scolar Press Ltd., 1971.
} 
emphasis to decorative, affective figures in movements that are designed to further the central argument. This requires a clear concept of each expressive gesture in the music, aptly delivered through the performer's skill in pronunciatio, which creates a sense of drama in preparation for the central argument in movement six.

A broad understanding of traditions and practices akin to the skills of an orator are essential to affective communication of musical figures. In Elements of Vocal Science (1824), Richard Bacon describes how the singer should develop these skills:

The student ought first to consider the appropriate delivery of the words before he tries them in combination with the air [aria]. Having thus determined how the words ought to be read [spoken aloud], he will proceed in the adaptation of them to melody. ${ }^{I}$

The effects of reading or declamation are produced by the quality of tone, by inflexion, by emphasis, and by total cessations or pauses. Singing seems only to heighten these effects by using in a bolder manner the same agents. The principles of both are the same. ${ }^{2}$

Applying these practices to figures such as anadiplosis and epizeuxis requires that the second iteration of a word or phrase be given with greater vehemence. Likewise, the appellations 'Wonderful, Councilor, the mighty God, the everlasting Father, the Prince of Peace' require the performer to consider how much emphasis will be given to each name, the declamatory nuance of each word, and what shape each phrase will assume.

In summary, it is incumbent on the conductor to understand the theological and rhetorical underpinnings of Bach's motets while being cognizant of the musical-rhetorical figures that give life to their structure. Similarly, a stirring, affective performance of Handel's Messiah demands a clear understanding of the purpose of musical-rhetorical figures found in each chorus and aria. Applying the skills of an orator to the text is of utmost importance in determining the phrasing, tone, dynamic nuance, and articulation of each word and phrase. It is ultimately the text, given musical expression through a declamatory delivery that gives Baroque choral works a sense of vibrancy and immediacy, thus engendering the passionate listener.

\section{Bibliography}

Bach, Johann Sebastian, ed. Konrad Ameln (1965). Neue Ausgabe sämtliche Werke: Motten. Kassel: Bärenreiter.

\footnotetext{
${ }^{1}$ Richard Bacon (1824), ed. Edward Foreman. Elements of Vocal Science; Being a Philosophical Enquiry Into Some of the Principles of Singing. Champaign, Ill: Pro Musica Press. 78.

${ }^{2}$ Ibid. 73.
} 
Bacon, Richard (1824), ed. Edward Foreman. Elements of Vocal Science; Being a Philosophical Enquiry Into Some of the Principles of Singing. Champaign, Ill: Pro Musica Press.

Bartel, Dietrch (1997). Musica Poetica: Musical-Rhetorical Figures in German Baroque music. Lincoln: University of Nebraska Press.

Burmeister, Joachim (1606). Musica Poetica, Rostok. Trans. Benito V. Rivera (1993). Musical Poetics. New Haven: Yale University Press.

Buszin, Walter E. (1946). 'Luther on Music.' Musical Quarterly.

Butt, John (2012). Bach's Dialogue with Modernity. Cambridge:Cambridge University Press.

Forkel, Johann (1788). Geschichte der Musik. Leipzig.

Gottshed, Johann Christoph (1736). Ausführliche Redekunst nach Anleitung der Greichen and Römer wie auch der neuern Ausländer. Leipzig: Breitkopf.

Kircher, Athenasius (1650). Musurgia Universalis sive ars magna consoni et dissoni. Rome.

Mattheson, Johann (1739). Der vollkommene Capellmeister. Hamburg: Christian Herold.

Henry Peacham the Elder (1577). The Garden of Eloquence. Menston: The Scolar Press Ltd., 1971.

Peacham the Elder, Henry (1593). The Garden of Eloquence. London.

Scheibe, Johann (1740). Critischer Musicus. Hamburg.

Walther, Johann Gottfried (1732). Musikalisches Lexicon. Leipzig: Wolfgang Deer. 